\title{
Murici, fruit from the Cerrado of Minas Gerais, Brazil: physical and physicochemical characteristics, and occurrence and concentration of carotenoids and vitamins
}

Fabiana R. HAMACEK ${ }^{1 *}$, Hércia S.D. MARTINO ${ }^{2}$, Helena M. PINHeIRO-SANT’ANA ${ }^{1}$

${ }^{1}$ Lab. Vitam. Anal., Nutr. Health Dep., Univ. Fed. Viçosa, PH Rolfs Avenue, Viçosa, 36570-900, Minas Gerais, Brazil,

frhamacek@yahoo.com.br

${ }^{2}$ Nutr. Health Dep., Univ. Fed. Viçosa, PH Rolfs Avenue, Viçosa, 36570-900, Minas Gerais, Brazil

${ }^{*}$ Correspondence and reprints

Received 7 February 2014 Accepted 26 March 2014

Fruits, 2014, vol. 69, p. 459-472 (C) 2014 Cirad/EDP Sciences All rights reserved

DOI: $10.1051 /$ fruits/2014032 www.fruits-journal.org

RESUMEN EsPañol, p. 472
Murici, fruit from the Cerrado of Minas Gerais, Brazil: physical and physicochemical characteristics, and occurrence and concentration of carotenoids and vitamins.

Abstract - Introduction. The Cerrado is the largest biome in the state of Minas Gerais, Brazil; it presents an enormous biodiversity represented by fruit species, highlighting murici (Byrsonima verbascifolia). The objective of our study was to investigate the physical and physicochemical characteristics, occurrence and concentration of carotenoids, vitamin C, vitamin E and folates in murici fruits from the Cerrado of Minas Gerais, Brazil. Materials and methods. Titratable acidity was determined by volumetric neutralization, $\mathrm{pH}$ by potentiometry, soluble solids by refractometry, moisture using an oven, ash using a muffle furnace, protein by the micro-Kjeldahl method, total dietary fiber by the nonenzymatic gravimetric method and lipids by Soxhlet extraction; carotenoids and vitamin $\mathrm{C}$ were analyzed by HPLC-DAD, and vitamin E and folates by HPLC with fluorescence detection. Results and discussion. The murici pulp contained $7.47 \mathrm{~g} \cdot 100 \mathrm{~g}^{-1}$ carbohydrates, $5.13 \mathrm{~g} \cdot 100 \mathrm{~g}^{-1}$ lipids, $13.58 \mathrm{~g} \cdot 100 \mathrm{~g}^{-1}$ fibers and $71.58 \mathrm{~g} \cdot 100 \mathrm{~g}^{-1}$ moisture. The $\mathrm{pH}$, titratable acidity and soluble solids were $3.93,0.77 \mathrm{~g}$ citric acid $100 \mathrm{~g}^{-1}$ and $10.73{ }^{\circ} \mathrm{Brix}$, respectively. The results indicated that the fruit is an excellent source of fiber and vitamin $\mathrm{C}\left(27.24 \mathrm{mg} \cdot 100 \mathrm{~g}^{-1}\right)$, a good source of vitamin $\mathrm{E}$ $\left(1819.72 \mu \mathrm{g} \cdot 100 \mathrm{~g}^{-1}\right)$ for children and a source for adults and pregnant women. Folates were not found in murici. Conclusion. Murici stands out with regard to its nutritional value and can contribute significantly to the supply of nutrients, especially fiber and vitamin C. Thus, consumption of these fruits should be encouraged among families residing in the Cerrado and in other regions of Brazil.

Brazil / Byrsonima verbascifolia / fruits / physicochemical properties / proximate composition / vitamin C / vitamin E / B vitamins

Le murici, fruit du Cerrado du Minas Gerais au Brésil : caractéristiques, physiques et physico-chimiques, occurrence et concentrations des carotenoïdes et des vitamines.

Résumé - Introduction. Le Cerrado est le plus vaste biome de l'état de Minas Gerais au Brésil ; il dispose d'une importante biodiversité d'espèces fruitières, parmi lesquelles la présence du murici (Byrsonima verbascifolia) mérite d'être soulignée. L'objectif de notre étude a été d'étudier les caractéristiques physiques et physico-chimiques, l'occurrence et la concentration des carotenoïdes, de la vitamine $\mathrm{C}$, de la vitamine $\mathrm{E}$ et des folates dans le fruit du murici collecté dans le Cerrado du Minas Gerais au Brésil. Matériel et méthodes. L'acidité titrable a été déterminée par neutralisation volumétrique, le pH par potentiométrie, les solides solubles par réfractométrie, l'humidité à l'aide d'un four, les cendres en utilisant un four à moufle, les protéines par la méthode de micro-Kjeldahl, les fibres alimentaires totales par la méthode de gravimétrie non-enzymatique et les lipides par l'extraction de Soxhlet ; des carotenoïdes et la vitamine C ont été analysés par HPLC-DAD, et la vitamine E et les folates l'ont été par HPLC avec détection de fluorescence. Résultats et discussion. La pulpe de murici contient 7,47 g.100 g ${ }^{-1}$ d'hydrates de carbone, 5,13 g.100 g de lipides, $13,58 \mathrm{~g} \cdot 100 \mathrm{~g}^{-1} \mathrm{de}$ fibres et $71.58 \mathrm{~g} \cdot 100 \mathrm{~g}^{-1}$ d'humidité. Le $\mathrm{pH}$, l'acidité titrable et les solides solubles ont été, respectivement, de $3,93,0,77 \mathrm{~g} \cdot 100 \mathrm{~g}^{-1}$ d'acide citrique et de $10,73{ }^{\circ} \mathrm{brix}$. Les résultats ont indiqué que le fruit est une excellente source de fibres et de vitamine $C(27,24 \mathrm{mg} \cdot 100 \mathrm{~g})^{-1}$, une bonne source de vitamine $\mathrm{E}\left(1819,72 \mu \mathrm{g} \cdot 100 \mathrm{~g}^{-1}\right)$ pour les enfants et une source pour les adultes et les femmes enceintes. Nous n'avons pas trouvé de folates dans le murici. Conclusion. Le murici se démarque grâce à sa valeur nutritive. Il pourrait contribuer de manière significative à l'apport en éléments nutritifs, notamment en fibres et vitamine $\mathrm{C}$. La consommation de ce fruit devrait donc être stimulée auprès des familles résidant dans le Cerrado et dans d'autres régions du Brésil.

Brésil / Byrsonima verbascifolia / fruits / propriété physicochimique / composition globale / vitamine $C$ / vitamine $E$ / complexe vitaminique $B$ 


\section{Introduction}

The Cerrado is considered the largest biome in the state of Minas Gerais, covering much of the northern and western portions of the state; it is the second largest in Brazil, only smaller than the Amazon rainforest. It covers an area of over two million square kilometers, representing approximately $22 \%$ of the national territory, distributed predominantly among the states of Minas Gerais, Goiás, Tocantins, Bahia, Ceará, Maranhão, Mato Grosso, Mato Grosso do Sul, Piauí, Rondônia and São Paulo [1, 2].

However, in recent decades, the Brazilian Cerrado has suffered severe degradation, where agricultural expansion, with extensive pastures and large monocultures, disregards the native vegetation and contributes to reduction of the original cover, thereby contributing to reducing its biodiversity [3]. According to the NGO Conservation International, the Cerrado is considered a "hotspot"; in other words, one of the richest and most threatened biomes on the planet [4].

The biodiversity of the Brazilian Cerrado is represented by the variety of fruit species found in this biome, including Byrsonima verbascifolia belonging to the family Malpighiaceae, which is known in Brazil as douradinha-falsa, mirici, muricizinho, orelha-de-burro and orelha-deveado. The murici, fruit of $B$. verbascifolia, can be consumed in natura by the population. When ripe, it presents a yellow color with a strong odor similar to that of stale cheese [5, 6]. The pulp is fleshy and soft, and can also be consumed in the form of juices, jellies, ice creams and liquors [6].

However, despite the use of murici pulp for various purposes, there is no data on the nutritional content of the fruit in the specialized literature and Brazilian food composition tables; especially, there is no data in relation to concentrations of carotenoids and vitamins studied with reliable analysis methods such as high-performance liquid chromatography (HPLC). Thus, the objective of our study was to physically and physicochemically characterize and investigate the occurrence and concentration of carotenoids and vitamins, as well as categorize murici from the Cerrado of Minas Gerais, Brazil, with regard to its nutritional value.

\section{Materials and methods}

\subsection{Raw material}

Murici fruits (B. verbascifolia) were collected directly from random trees during its harvest season (November 2010 to March 2011) in an area of native vegetation typical of the Cerrado, located in the northern region of the state of Minas Gerais, Brazil, in the city of Januária (lat. $15^{\circ} 29^{\prime} \mathrm{S}$ and long. $\left.44^{\circ} 21^{\prime} \mathrm{W}\right)$.

\subsection{Collection and preparation of the samples}

To obtain five replicates the collection area was divided into five sub-areas, where approximately $200 \mathrm{~g}$ of murici (60 units) were collected in each area. In the laboratory, fruits were selected according to the degree of maturation and absence of injuries, based on the characteristic parameters of color and texture of the fruit. Ripe fruits were considered those with predominantly yellow skin and soft texture. The morphologically perfect and completely ripe fruits were washed with tap water to eliminate surface dirt from the site collection and dried on paper towels.

The pulp obtained was homogenized using a domestic food processor (Faet Multipratic, MC5, Brazil), packaged in polyethylene bags, labeled, wrapped in aluminum foil and stored at $(-18 \pm 1){ }^{\circ} \mathrm{C}$.

\subsection{Standards of carotenoids and vitamins}

The standards of $\alpha$-carotene and $\beta$-carotene were isolated from concentrated extract of carrot, while $\beta$-cryptoxanthin and lycopene were isolated from extracts of papaya and tomato, respectively, by open column chromatography, according to RodriguesAmaya [7]. L-ascorbic acid was purchased 
from Sigma-Aldrich ${ }^{\circledR}$ (Germany). The vitamin E standards $(\alpha-, \beta-, \gamma$ - and $\delta$-tocopherol and tocotrienol) were purchased from Calbiochem ${ }^{\circledR}$, EMD Biosciences, Inc. (USA). The folate standards used [(6S)-5,6,7,8sodium tetrahydrofolate (THF), (6S)-5methyl-5,6,7, 8-tetrahydrofolate (5-MTHF) and (6S) 5-formyl-5,6,7,8-tetrahydrofolate (5-FTHF)] were provided by MerckEprova $^{\circledR}$ (Switzerland).

\subsection{Physical characterization}

Individual measurements of diameter and length were carried out on 30 murici fruits using a digital caliper rule (Mitutoyo, Brazil). The mass of fruit (MFr), mass of the pulp $(\mathrm{MPu})$ and seed mass were obtained by individual direct weighing on a semianalytical balance (Gehaka, BG 2000, Brazil).The pulp yield was calculated using the equation $[(\mathrm{MPu} / \mathrm{MFr}) \times 100]$.

\subsection{Physicochemical analyses}

The physicochemical analyses were performed in three repetitions. Titratable acidity, soluble solids and $\mathrm{pH}$ were determined according to the methodologies proposed by the Instituto Adolfo Lutz [8]; moisture, ash, protein, lipids and total dietary fiber were determined according to the methods of the Association of Official Analytical Chemistry [9]. Carbohydrate concentrations were estimated by the equation: [100 $(\%$ moisture $+\%$ fat $+\%$ protein $+\%$ total dietary fiber $+\%$ ash)]. The total energy was estimated considering the conversion factors of $4 \mathrm{kcal} \cdot \mathrm{g}^{-1}$ for protein and carboydrate, and $9 \mathrm{kcal} \cdot \mathrm{g}^{-1}$ for lipids [9].

\subsection{Extraction and analyses of carotenoids and vitamins}

The extraction and analysis were performed in five repetitions. During the steps of extraction and analysis, the samples and extracts were protected from both sunlight and artificial light with the use of amber glass bottles, aluminum foil and blackout curtains, and they were also protected from oxygen by using lids and environments with nitrogen gas in glass bottles.

\subsection{Carotenoids}

The occurrence and concentration of $\alpha$-carotene, $\beta$-carotene, $\beta$-cryptoxanthin and lycopene were investigated in murici pulp. Extraction was performed using the method proposed by Rodriguez-Amaya et al. [10].

About $5 \mathrm{~g}$ of pulp were weighed, supplemented with $60 \mathrm{~mL}$ of cooled acetone (divided into three volumes of $20 \mathrm{~mL}$ ), homogenized in a micro-crusher (Marconi, MA 102, Brazil) for approximately $3 \mathrm{~min}$, and vacuum-filtered in a Büchner funnel using filter paper. Then, the filtrate was transferred in three fractions to a separatory funnel containing $50 \mathrm{~mL}$ of cooled petroleum ether. Each fraction was washed with distilled water for complete removal of acetone. Anhydrous sodium sulfate was added to the ether extract to remove any residual water. Subsequently, the ether extract was concentrated using a rotary evaporator (Tecnal, TE-211, Brazil) at $(35 \pm 1)^{\circ} \mathrm{C}$ and transferred to a $25-\mathrm{mL}$ volumetric flask, where the volume was completed with petroleum ether. This extract was then transferred to a hermetically sealed amber glass bottle and stored at $(-18 \pm 1){ }^{\circ} \mathrm{C}$.

For chromatographic analysis, an aliquot of $10 \mathrm{~mL}$ of the extract was evaporated under a flow of nitrogen gas, and the dry residue was dissolved in $2 \mathrm{~mL}$ HPLC-grade acetone (Tedia, Brazil). The extracts were filtered through HV Millex filter units made of polyethylene, with $0.45 \mu \mathrm{m}$ porosity (Millipore, Brazil).

Carotenoid analysis was carried out by HPLC using a HPLC system (Shimadzu, SCL 10at VP, Japan) coupled to a diode array detector (DAD) (Shimadzu, SPD-M10A, Japan), and the chromatographic conditions developed by Pinheiro-Sant'Ana et al. [11]: a chromatographic column (Phenomenex Gemini RP-18, $250 \mathrm{~mm} \times 4.6 \mathrm{~mm}$, $5 \mathrm{~mm}$ ), equipped with a guard column (Phenomenex ODS, $4 \mathrm{~mm} \times 3 \mathrm{~mm}$ ), a mobile phase of methanol:ethyl acetate:acetonitrile $(70: 20: 10, \mathrm{v} / \mathrm{v} / \mathrm{v})$ at a flow rate of $2 \mathrm{~mL} \cdot \mathrm{min}^{-1}$, injection of sample: $50 \mu \mathrm{L}$; running time $15 \mathrm{~min}$. Chromatograms were obtained at $450 \mathrm{~nm}$. 
Vitamin A concentrations were calculated according to the recommendations of the Institute of Medicine [12], in which 1 Retinol Activity Equivalent (RAE) corresponds to $1 \mu \mathrm{g}$ of retinol, $12 \mu \mathrm{g}$ of $\beta$-carotene, or $24 \mu \mathrm{g}$ of other provitamin A carotenoids.

\subsection{Vitamin C}

The extraction and analysis of ascorbic acid and conversion of dehydroascorbic acid into ascorbic acid were performed according to the conditions proposed by Campos et al. [13].

For the extraction, about $5 \mathrm{~g}$ of pulp were ground for about $3 \mathrm{~min}$ in $15 \mathrm{~mL}$ of extraction solution composed of ultrapure water supplemented with metaphosphoric acid 3\%, acetic acid 8\%, sulfuric acid $0.8 \%$ and EDTA $0.0294 \%$. The extract was centrifuged (Fanem, Excelsa Baby II-206R, Brazil) at $4,000 \mathrm{rpm}(1,789 \mathrm{~g})$ for $15 \mathrm{~min}$, vacuumfiltered on filter paper in a Buchner funnel, and diluted to $25 \mathrm{~mL}$ in a volumetric flask with ultrapure water. Subsequently, the extract was again centrifuged at $14,000 \mathrm{rpm}$ $(21,913 \mathrm{~g})$ for $5 \mathrm{~min}$ and the supernatant stored under refrigeration $(5 \pm 1)^{\circ} \mathrm{C}$ until analysis.

For the conversion of dehydroascorbic acid into ascorbic acid, a $1.0-\mathrm{mL}$ aliquot of the extract obtained in the extraction of ascorbic acid was pipetted into an amber glass bottle and added to $1.0 \mathrm{~mL}$ of $1.2 \mathrm{M}$ Trizma buffer solution ( $\mathrm{pH} 9.0)$ containing $40 \mathrm{mM}$ dithiothreitol (DTT) (Sigma-Aldrich, Germany) to increase the $\mathrm{pH}$ to near neutrality (pH 6.0). The extract was kept at rest for $10 \mathrm{~min}$ at room temperature and protected from light. Subsequently, the $\mathrm{pH}$ of the extract was reduced to 2 by the addition of $0.5 \mathrm{~mL}$ of $0.4 \mathrm{mM} \mathrm{H}_{2} \mathrm{SO}_{4}$.

The ascorbic acid analyses were performed by injection of $30 \mu \mathrm{L}$ of the extract previously filtered in filter units with porosity of $0.45 \mu \mathrm{m}$. The analyses were performed using the same HPLC system employed in the analysis of carotenoids and the following chromatographic conditions were used: HPLC-DAD system, RP18 chromatography column (Lichrospher $100,250 \mathrm{~mm} \times 4 \mathrm{~mm}, 5 \mathrm{~mm}$ ), mobile phase consisting of ultrapure water with $1 \mathrm{mM}$ $\mathrm{NaH}_{2} \mathrm{PO}_{4}, 1 \mathrm{mM}$ EDTA and $\mathrm{pH}$ adjusted to 3.0 with $\mathrm{H}_{3} \mathrm{PO}_{4}$, and mobile phase flow of $1.0 \mathrm{~mL} \cdot \mathrm{min}^{-1}$. Chromatograms were obtained at $250 \mathrm{~nm}$ [13].

The total concentration of vitamin $\mathrm{C}$ was calculated by the sum of ascorbic acid and dehydroascorbic acid found in the samples.

\subsection{Vitamin E}

The extraction and analysis of the eight components of vitamin $\mathrm{E}(\alpha-, \beta-, \gamma-$ and $\delta$-tocopherols and $\alpha-, \beta-, \gamma$ and $\delta$-tocotrienols) were performed according to Pinheiro-Sant'Ana et al. [14].

Approximately $10 \mathrm{~g}$ of pulp were supplemented with $4 \mathrm{~mL}$ of heated ultrapure water [(about $(80 \pm 1){ }^{\circ} \mathrm{C}$ ], ten $\mathrm{mL}$ of isopropyl alcohol, one $\mathrm{mL}$ of hexane containing BHT $0.05 \%$ and $5 \mathrm{~g}$ of anhydrous sodium sulfate. Gradually, twenty-five $\mathrm{mL}$ of the extraction solvent mixture (hexane:ethyl acetate, $85: 15$, v/v) were added to the suspension. After these procedures, the suspension was homogenized in a microcrusher at average speed for $1 \mathrm{~min}$. Once ground, the sample was vacuum-filtered through filter paper in a Büchner funnel, and the residue was maintained in an extraction tube.

The extraction was repeated with the addition of $5 \mathrm{~mL}$ of isopropyl alcohol and $3 \mathrm{~mL}$ of the solvent mixture, with subsequent homogenization and vacuum filtration. Then the extract was concentrated in a rotary evaporator at $(70 \pm 1){ }^{\circ} \mathrm{C}$ for about $2 \mathrm{~min}$, transferred to a volumetric flask and the volume completed to $25 \mathrm{~mL}$ with the solvent mixture.

After extraction, five $\mathrm{mL}$ of the extracts were dried in nitrogen gas, redissolved in $2.0 \mathrm{~mL}$ of HPLC-grade hexane and filtered through filter units with porosity of $0.45 \mu \mathrm{m}$. The analysis of the different components of vitamin E was performed by HPLC (Shimadzu SCL 10AD VP, Japan) comprising a high-pressure pump (Shimadzu LC-10AD $\mathrm{VP}$, Japan), an autosampler with a $50-\mu \mathrm{L}$ loop (Shimadzu SIL-10AF, Japan) and a fluorescence detector (Shimadzu, RF10AXL, Japan). 
The chromatographic conditions used for the analysis included: fluorescence detection (excitation at $290 \mathrm{~nm}$ and emission at $330 \mathrm{~nm}$ ); a Luna chromatographic column (Phenomenex, Si60, $250 \mathrm{~mm} \times 4 \mathrm{~mm}$, $5 \mathrm{~mm}$ ), equipped with a guard column (Phenomenex, Si60, $4 \mathrm{~mm} \times 3 \mathrm{~mm}$ ), a mobile phase composed of: hexane:isopropanol:acetic acid in the proportions of 98.9:0.6:0.5, a mobile phase flow rate of $1.0 \mathrm{~mL} \cdot \mathrm{min}^{-1}$ and injection of the sample: $10 \mu \mathrm{L}$. The total concentration of vitamin $\mathrm{E}$ was calculated by the sum of the components of vitamin $\mathrm{E}$ identified in the samples [14].

\subsection{Folates}

The occurrence of three folate forms (THF, 5-MTHF and 5-FTHF) was investigated, with the extraction and analysis performed according to Della Lucia et al. [15]. Approximately $5 \mathrm{~g}$ of the pulp were ground in $20 \mathrm{~mL}$ of phosphate buffer solution $0.1 \mathrm{M}$, $\mathrm{pH}$ 6.0, containing ascorbic acid $1 \%$ and 2-mercaptoethanol $0.1 \%$. The suspension was centrifuged at $4,000 \mathrm{rpm}(1,789 \mathrm{~g})$ for $15 \mathrm{~min}$, vacum-filtered in a Buchner funnel using filter paper, and diluted to $25 \mathrm{~mL}$ in a volumetric flask with ultrapure water. Then, the extract was heated for about $12 \mathrm{~min}$ in a water bath at $(100 \pm 1){ }^{\circ} \mathrm{C}$ and cooled in an ice bath until the temperature fell below $(37 \pm 1)^{\circ} \mathrm{C}$.

The cooled extract was centrifuged again at $4,000 \mathrm{rpm}(1,789 \mathrm{~g})$ for $15 \mathrm{~min}$ and submitted to deconjugation of the polyglutamates into monoglutamates. For deconjugation, rat plasma $(100 \mu \mathrm{L})$ containing the enzyme conjugase ( $\gamma$-glutamyl carboxypeptidase) was added to $3 \mathrm{~mL}$ of the previously obtained supernatant, and the extract was incubated in a water bath at $(37 \pm 1)^{\circ} \mathrm{C}$ for $3 \mathrm{~h}$. Then, the extract was heated in boiling water for 5 min to inactivate the enzyme.

Extract purification was performed using an ion-exchange column with a stationary phase of Q-Sepharose Fast Flow (Pharmacia, USA). The column was pre-conditioned with methanol (Tedia, Brazil) and water (1:1), and the extract was applied to the column at a flow rate of 2 drops per second. Then, retained folates were eluted in $1.5 \mathrm{~mL}$ of sodium acetate $(0.1 \mathrm{M})$ containing $10 \%$ $\mathrm{NaCl}, 1 \%$ ascorbic acid and $0.1 \%$ 2-mercaptoethanol.

Analyses were performed by injection of $50 \mu \mathrm{L}$ of the extracts previously filtered through filter units with a porosity of $0.45 \mu \mathrm{m}$ into the same system used for analysis of vitamin $\mathrm{E}$, complemented with a mobile phase degassing system utilizing helium (Shimadzu DGU-2, Japan). The chromatographic conditions used for analysis included: HPLC system; a ShimPack 100 RP18 chromatography column $(150 \mathrm{~mm} \times$ $4.6 \mathrm{~mm}, 4.6 \mu \mathrm{m}$ ) (Merck, Germany), and a mobile phase composed of phosphate buffer $\left(30 \mathrm{mM} \mathrm{NaH} \mathrm{PO}_{4}, \mathrm{pH}\right.$ adjusted to 2.3 with $\mathrm{H}_{3} \mathrm{PO}_{4}$ ) as eluent $\mathrm{A}$ and acetonitrile as eluent $\mathrm{B}$.

The binary gradient utilized was as follows: from ( 0 to 5 ) $\mathrm{min}, 94 \%$ of eluent $\mathrm{A}$ $+6 \%$ of eluent B; from ( 5 to 25 ) min, linear gradient to $75 \%$ of eluent $\mathrm{A}+25 \%$ of eluent B, from ( 25 to 33 ) $\mathrm{min}, 75 \%$ of eluent $A$ $+25 \%$ of eluent B, from (33 to 35 ) $\mathrm{min}$, return to initial conditions followed by a stabilization period of up to $50 \mathrm{~min}$. The mobile phase flow rate was $0.7 \mathrm{~mL} \cdot \mathrm{min}^{-1}$. The mobile phase was degassed with helium gas for $15 \mathrm{~min}$ at $100 \mathrm{kPa}$ before initiating the analyses and $50 \mathrm{kPa}$ during runs [15].

\subsection{Identification and quantification of carotenoids and vitamins}

Qualitative identification of the compounds was performed by comparing the retention times obtained for standards and samples analyzed under the same conditions. In addition, carotenoids and ascorbic acid were identified by comparison of the absorption spectra of the standards and samples using the DAD, and the folates and vitamin $\mathrm{E}$ by co-chromatography.

Quantitation of the compounds was performed using external standardization curves. Appropriate dilutions were made from standard solutions in order to achieve concentrations comparable with those observed in fresh pulp of murici. For this, 
solutions for each compound present in the pulp of the fruit ( $\beta$-carotene, ascorbic acid, $\alpha$-tocopherol and $\beta$-tocotrienol) were prepared at different concentrations.

Construction of standard curves was taken by injection, in duplicate, with six increasing concentrations of the standard solutions in the range between $0.003 \mu \mathrm{g}$ and $0.112 \mu \mathrm{g}$ for $\beta$-carotene, $0.155 \mu \mathrm{g}$ and $7.750 \mu \mathrm{g}$ for ascorbic acid, $0.0010 \mu \mathrm{g}$ and $0.1042 \mu \mathrm{g}$ for $\alpha$-tocopherol, and $0.0020 \mu \mathrm{g}$ and $0.5100 \mu \mathrm{g}$ for $\beta$-tocotrienol. Thus, there was a linear correlation between the peak areas and concentrations of each compound injected.

Quantification of compounds in murici was performed on the analytical curves and regression equations achieved for $\beta$-carotene $(y=1421302.230 x+3563.819$; $\left.R^{2}=0.999\right) ; \operatorname{ascorbicacid}(y=1394501.207 x$ - 115382.946; $\left.R^{2}=0.993\right) ; \alpha$-tocopherol $(y=$ 93284137.0896x $\left.+47566.8009 ; R^{2}=0.997\right)$, and $\beta$-tocotrienol $(y=24797142.844 x+$ 285288.289; $\left.R^{2}=0.998\right)$. The real concentration was obtained by calculations based on the dilution factors.

\subsection{Quality control of the analytical methods}

Tests of recovery, linearity, repeatability, limit of detection (LOD) and limit of quantification (LOQ) were performed for quality control of the analytical methods used in the analysis of carotenoids and vitamins.

The recovery tests were performed by addition of standards ( $\beta$-carotene, ascorbic acid, $\alpha$-tocopherol and $\beta$-tocotrienol) to the samples. The amount of added standard ranged from $50 \%$ to $100 \%$ of the initial concentration observed in murici pulp. The percentage of recovery was calculated using the equation: \% recovery $=[($ final concentration of compound - concentration of added standard) / (initial concentration of compound $\times 100$ ]. All procedures were performed in triplicate.

The determination of the linearity range of the compounds was determined by injection, in duplicate, of six standard solutions with different concentrations, using the same chromatographic conditions used for the analysis of the extract. The data obtained from the peak areas were used for linear regression analysis. The coefficient of determination $\left(R^{2}\right)$ obtained in each case was used to evaluate the linearity [16].

Repeatability tests were performed by extraction and analysis in five replications of the same repeat containing vitamins found. The repeatability was evaluated by calculating the relative standard deviation (RSD) of the peak areas and retention times of the analyzed components [16]. The limit of detection (LOD) was performed by successive dilutions of standards followed by determination of the smallest detectable amount. The LOD was established as three times the amplitude of the baseline noise and the limit of quantification as ten times the LOD [17].

\subsection{Categorization of murici as a source of nutrients and fiber}

The categorization of a portion of murici pulp as a source of fiber and vitamins for children (4-8 years), pregnant women and adult men (19-30 years) was performed according to Philippi, who classifies food as a "source" supplying nutrients when it provides 5-10\% of the Dietary Reference Intake (DRI), "good source" when it supplies 10$20 \%$ of the DRI and "excellent source" of nutrients when supplying more than $20 \%$ of the DRI [18].

\subsection{Experimental design and statistical analysis}

A completely randomized design with five replications, represented by the five batches of each fruit, was used for analyses of the concentration of carotenoids and vitamins, with three replicates for physicochemical analyses. Data was stored in spreadsheets using the Microsoft Office Excel software system, version 2007. Calculation of the mean, standard deviation and range of parameters was performed using SAS software (Statistical Analysis System), version 9.2 (2008), licensed to the Federal University of Viçosa (UFV), Brazil. 


\section{Results and discussion}

\subsection{Physical characterization}

The murici fruits presented a rounded shape, slightly flattened, with a thin bright yellow skin. Their pulp is juicy, fleshy, oily and yellowish, with a strong odor, containing a small seed in its interior (figure 1).

The average pulp mass of each fruit was $2.78 \mathrm{~g}$, ranging from $1.43 \mathrm{~g}$ to $4.41 \mathrm{~g}$ with yield of $79.04 \%$ (table I), which may result in good technological use of the fruit for the development of products. The average pulp mass was higher than the $1.99 \mathrm{~g}$ found by Gusmão et al. [19] in fruit of the same species collected in the municipality of Montes Claros, Minas Gerais, Brazil. The pulp yield was also higher than the $63 \%$ reported by Araújo et al. [20] in fruits collected in the Cerrado region of the state of Alagoas, Brazil. These different results may be due to soil and climatic differences between the places of fruit collection.

\subsection{Physicochemical characterization}

The soluble solids concentration found in the murici pulp of fruit from Minas Gerais, Brazil (10.73 ${ }^{\circ}$ Brix) (table II) was similar to that reported by Guimarães and Silva [21] $\left(10.67^{\circ} \mathrm{Brix}\right)$ in fruits collected in the state of Goiás, and higher than that found by Canuto et al. [22] in fruits from the Amazon $\left(1.5^{\circ} \mathrm{Brix}\right)$. The higher soluble solids content found in our study compared with that reported in previous studies may be explained by the difference in the states (which have different climates) in which the

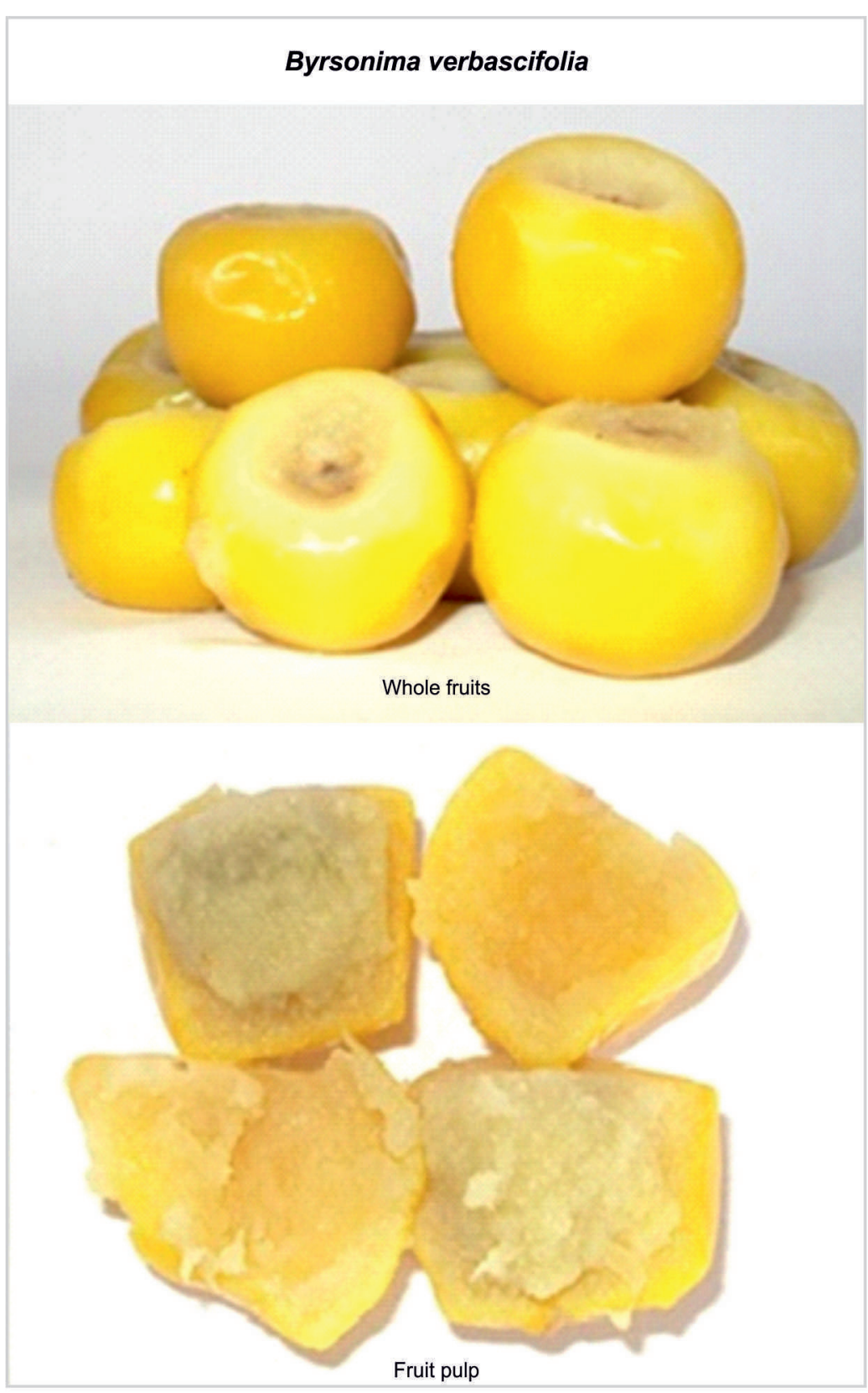

Figure 1.

Whole fruit and fruit pulp of murici (Byrsonima verbascifolia).
Mean \pm standard deviation of physical characteristics of 30 fruits of murici (Byrsonima verbascifolia) from the Cerrado (Januária, Minas Gerais, Brazil).

\begin{tabular}{lcccccc} 
Parameters & $\begin{array}{c}\text { Diameter } \\
(\mathrm{cm})\end{array}$ & $\begin{array}{c}\text { Height } \\
(\mathrm{cm})\end{array}$ & Fruit & Seeds & Pulp & $\begin{array}{c}\text { Pulp yield } \\
(\%)\end{array}$ \\
\hline Mean & $1.82 \pm 0.17$ & $1.36 \pm 0.11$ & $3.51 \pm 0.87$ & $0.73 \pm 0.19$ & $2.78 \pm 0.71$ & $79.04 \pm 3.09$ \\
Minimum & 1.40 & 1.10 & 1.74 & 1.23 & 1.43 & 71.43 \\
Maximum & 2.10 & 1.60 & 5.51 & 0.31 & 4.41 & 84.69
\end{tabular}


fruits were collected, and also by their ripeness. The contents of soluble solids correlate with the sugar and organic acid concentrations, which are parameters of interest for the marketing of fresh fruit due to the preference of consumers for sweet fruits [22].

Another criterion for the classification of fruit flavor, odor, stability and quality is the determination of the titratable acidity [23]. The titratable acid concentration we found in Minas Gerais $\left(0.77 \mathrm{~g}\right.$ citric acid $\left.100 \mathrm{~g}^{-1}\right)$ (table II) was similar to that found by Canuto et al. [24] in fruit pulp of the same species collected in the Amazon (1.0 g citric acid $100 \mathrm{~g}^{-1}$ ). The [soluble solids/titratable acid] ratio obtained in our study was high (3.93). This parameter is related to fruit quality in terms of maturity and flavor, showing the balance between sugars and acidity which makes it more palatable, highlighting its sweet and pleasant taste [23].

The murici pulp in the fruits we collected in Minas Gerais presented a $\mathrm{pH}$ greater than the 3.42 reported by Guimarães and Silva [21] in fruits collected in Goiás, and pH 3.7 observed by Canuto et al. [24] in fruits of the Amazon.

The concentration of dietary fiber in murici fruits from the Cerrado of Minas Gerais, Brazil, was $13.58 \mathrm{~g} \cdot 100 \mathrm{~g}^{-1}$ (table II); there, this fruit may be considered an excellent source of this component for children, adults and pregnant women, since the consumption of a portion of fruit pulp ( $86 \mathrm{~g}$ ) may contribute over $40 \%$ of daily needs in accordance with the recommendation of the Institute of Medicine [25]. Due to the high content of dietary fiber, murici can help control intestinal transit and reduce both serum glucose and cholesterol [26].

We observed a lower moisture content than that reported by Guimarães and Silva $\left(75.87 \mathrm{~g} \cdot 100 \mathrm{~g}^{-1}\right)$ [21] and by Silva et al. $\left(80.64 \mathrm{~g} .100 \mathrm{~g}^{-1}\right)$ [27] in fruits of the same species collected in the state of Goiás. The high moisture concentration in murici pulp, along with the fragility of its skin, makes this fruit highly susceptible to enzymatic and microbial spoilage, which complicates its conservation.
The murici pulp from the Cerrado in Minas Gerais showed carbohydrate concentrations greater than the $5.96 \mathrm{~g} \cdot 100 \mathrm{~g}^{-1}$ observed by Silva et al. in fruits from the Cerrado collected in the state of Goiás, Brazil, [27]; however, this value is lower than the $19.62 \mathrm{~g} \cdot 100 \mathrm{~g}^{-1}$ observed by Guimarães and Silva in fruits also collected in the state of Goiás [21]. The lipid concentration was greater than the $2.19 \mathrm{~g} \cdot 100 \mathrm{~g}^{-1}$ [27] and $3.02 \mathrm{~g} \cdot 100 \mathrm{~g}^{-1}$ [21] reported for fruits collected in the state of Goias, Brazil.

In the murici pulp of the fruit we studied, the protein and ash concentrations were also higher than those reported by Silva et al. $\left(0.72 \mathrm{~g} \cdot 100 \mathrm{~g}^{-1}\right.$ and $0.78 \mathrm{~g} \cdot 100 \mathrm{~g}^{-1}$, respectively) [27] and Guimarães and Silva $\left(0.86 \mathrm{~g} \cdot 100 \mathrm{~g}^{-1}\right.$ and $0.63 \mathrm{~g} \cdot 100 \mathrm{~g}^{-1}$, respectively) [21] in fruit pulps found in the Cerrado of the state of Goiás, Brazil. The energy value of murici evaluated in our study was higher than the $46.43 \mathrm{kcal} \cdot 100 \mathrm{~g}^{-1}$ observed by Silva et al. [27]; however, it was lower than the $109.10 \mathrm{kcal} \cdot 100 \mathrm{~g}^{-1}$ which was found by Guimarães and Silva in a study with fruits from the Cerrado of Goiás, Brazil [21].

\subsection{Carotenoids and vitamins}

\subsubsection{Quality of analytical methods}

Tests for quality control of the analyses performed in our study showed that the assay conditions were reliable, with low probability of carotenoid and vitamin loss during extraction: they allowed the detection of low concentrations of the analyzed compounds (table III).

The recovery percentages of carotenoid and vitamin standards added to the murici extracts were excellent, ranging from $91.7 \%$ to $98.0 \%$ (table III). The repeatability test showed low values of relative standard deviation for peak areas (RSD-PA) and retention times (RSD-RT), which adds to the reliability of the analyses. A wide linearity range was observed for each compound examined and the coefficients of determination $\left(R^{2}\right)$ were greater than 0.993 . The limit of detection (LOD) for carotenoids and vitamins ranged from 0.025 to $12.321 \mu \mathrm{g} \cdot \mathrm{mL}^{-1}$. The limit of quantification 
(LOQ), considered as 10 times the value of the LOD, ranged from (0.251 to 123.21) $\mu \mathrm{g} \cdot \mathrm{mL}^{-1}$. Therefore, the LOD and LOQ obtained show that very small amounts of the vitamins can be detected and quantified by the method employed.

\subsubsection{Qualitative composition}

Murici pulp showed the presence of $\beta$-carotene (retention time-RT: $8.30 \mathrm{~min}$ ), ascorbic acid (RT: $3.51 \mathrm{~min}$ ), $\alpha$-tocopherol (RT: $6.45 \mathrm{~min}$ ) and $\beta$-tocotrienol (RT: $11.05 \mathrm{~min})$. In the murici samples we studied, we did not identify $\alpha$-carotene, $\beta$-cryptoxanthin, lycopene, $\beta$-, $\gamma$ - and $\delta$-tocopherol, $\alpha$-, $\gamma$ - and $\delta$-tocotrienol or the three forms of folate (figure 2).

\subsubsection{Vitamin content}

Studies on the concentration of vitamin C, vitamin $\mathrm{A}$, vitamin $\mathrm{E}$ and folates in murici fruits from the Cerrado of Minas Gerais, Brazil, were not found in the literature (table $I V$ ). In pulp of murici, the presence of vitamin C was observed both in the reduced (ascorbic acid) and in the oxidized forms (dehydroascorbicdehydroascorbic acid), where ascorbic acid corresponds to 82.92\% of the total vitamin C concentration. The concentration of vitamin $C$ found in murici pulp was higher than that of fruits conventionally consumed by the Brazilian population: pitanga $\left(26.3 \mathrm{mg} \cdot 100 \mathrm{~g}^{-1}\right)$, tangerine $\left(21.0 \mathrm{mg} \cdot 100 \mathrm{~g}^{-1}\right)$, melon $(18.0 \mathrm{mg}$. $100 \mathrm{~g}^{-1}$ ) and grapes $\left(10.8 \mathrm{mg} \cdot 100 \mathrm{~g}^{-1}\right)$; it was similar to that found in mango $\left(27.7 \mathrm{mg} \cdot 100 \mathrm{~g}^{-1}\right)$ [28]. The concentration of vitamin $C$ in murici pulp was also higher than that of other fruits found in the Cerrado of Minas Gerais, Brazil, such as boiled pequi (Caryocar brasiliense Camb.) (14.33 mg. $100 \mathrm{~g}^{-1}$ ) [29], jatobá (Hymenaea stigonocarpa) $\left(8.91 \mathrm{mg} \cdot 100 \mathrm{~g}^{-1}\right)$ [30], araticum (Annona crassiflora Mart.) (5.23 mg. $100 \mathrm{~g}^{-1}$ ) [31] and tamarind (Tamarindus indica $\mathrm{L}$.) $\left(4.79 \mathrm{mg} \cdot 100 \mathrm{~g}^{-1}\right)$ [32].

The concentration of vitamin A observed in murici was similar to nectarine $\left(0.15 \mathrm{mg} \cdot 100 \mathrm{~g}^{-1}\right)$ and higher than that found in strawberries $\left(0.02 \mathrm{mg} \cdot 100 \mathrm{~g}^{-1}\right)$ [33] and mangaba (Hancornia speciosa) $\left(7.5 \mathrm{mg} \cdot 100 \mathrm{~g}^{-1}\right)$ in the Cerrado of Minas
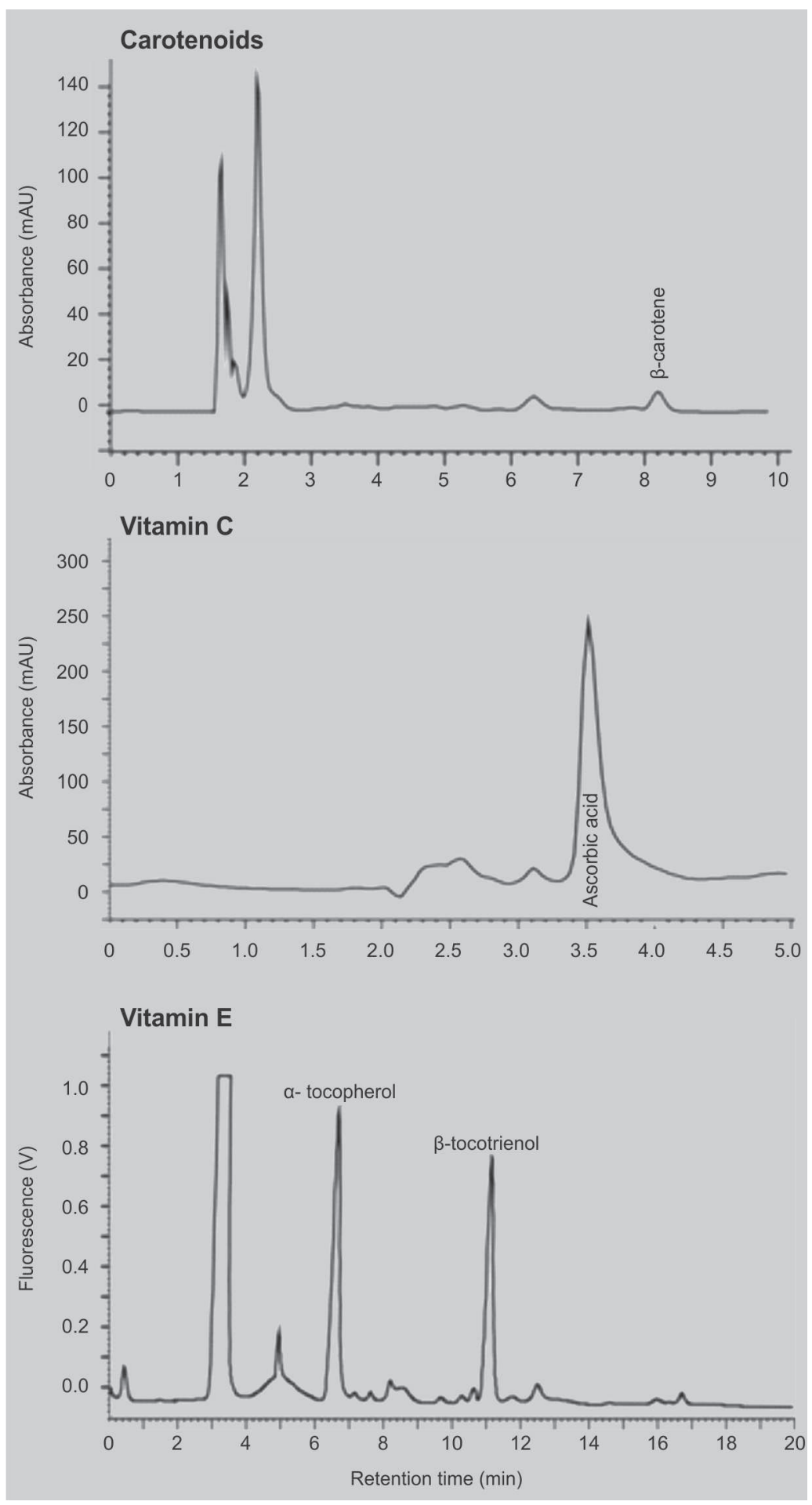

Figure 2.

HPLC analysis of carotenoids, vitamin C and vitamin E in murici pulp (Byrsonima verbascifolia) from the Cerrado of Minas Gerais (Januária, Minas Gerais, Brazil). 


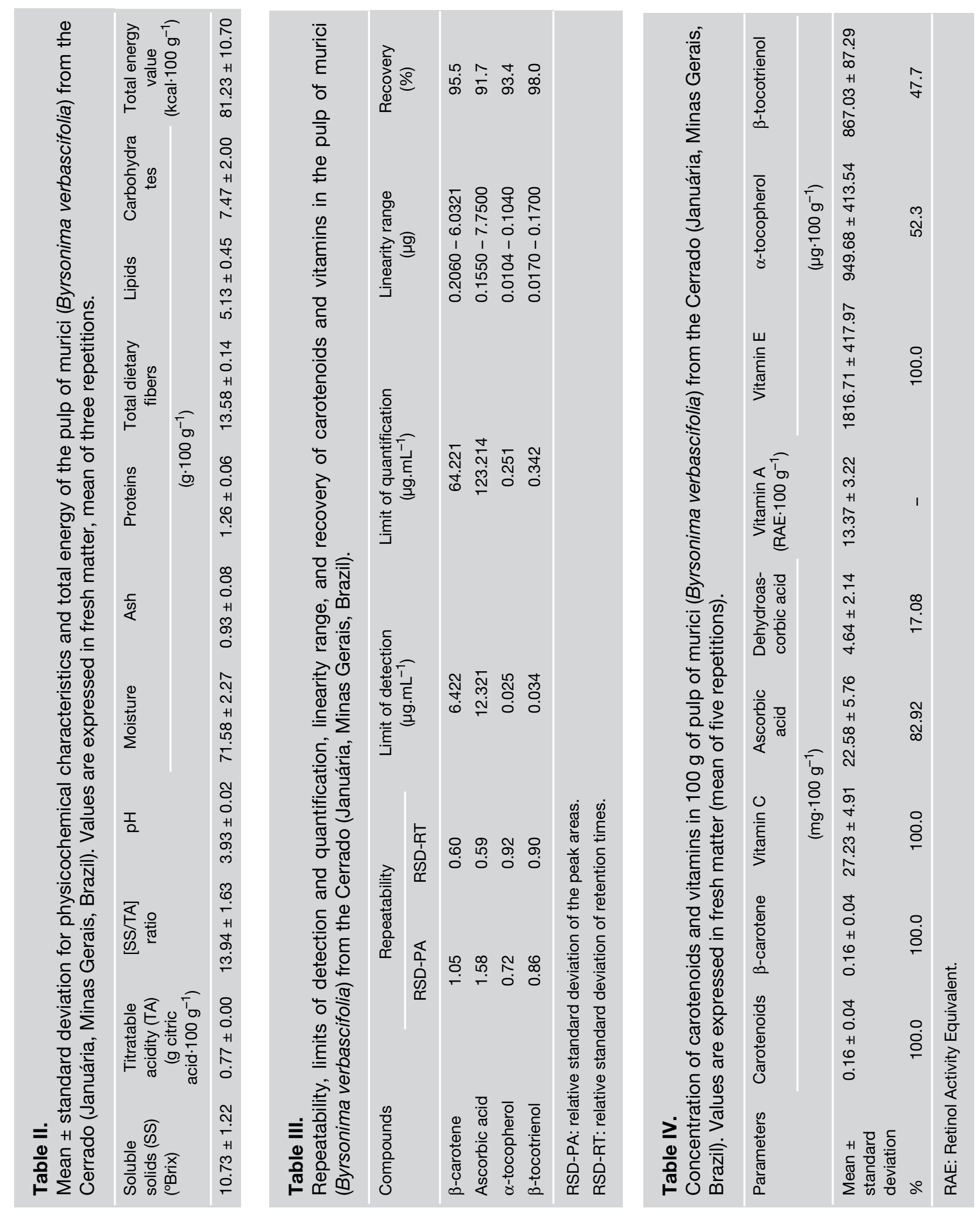


Gerais [34]. The concentration of vitamin E observed in the murici pulp was represented by the compounds $\alpha$-tocopherol and $\beta$-tocotrienol, corresponding to $52.3 \%$ and $47.7 \%$ of the total content, respectively (table IV). Murici showed a considerable vitamin $\mathrm{E}$ concentration, higher than that found in kiwi $\left(1450 \mu \mathrm{g} \cdot 100 \mathrm{~g}^{-1}\right)$ and peach $\left(1230 \mu \mathrm{g} \cdot 100 \mathrm{~g}^{-1}\right)$ [28]. The concentration was also higher than that of other fruits found in the Cerrado of Minas Gerais, Brazil, such as jatobá $\left(495.54 \mu \mathrm{g} \cdot 100 \mathrm{~g}^{-1}\right)$ [30], araçá (Psidium firmum O. Berg) $\left(336.33 \mu \mathrm{g} \cdot 100 \mathrm{~g}^{-1}\right)$ [35], baked pequi $\left(170.81 \mu \mathrm{g} \cdot 100 \mathrm{~g}^{-1}\right)$ [29] and tamarind $\left(108.78 \mu \mathrm{g} \cdot 100 \mathrm{~g}^{-1}\right)$ [32].

\subsubsection{Nutritional value of murici pulp as a source of vitamins and dietary fiber}

To study the potential contribution of murici pulp to supplying the daily recommendation of vitamins for children, adults and pregnant women, pulp portions were calculated according to the National Health Surveillance Agency/ANVISA, Resolution 39, which recommends the presence of $70 \mathrm{kcal}$ in a single fruit portion [36].

Consumption of 30 units of murici fruit, equivalent to $86 \mathrm{~g}$ of pulp (70 kcal), can contribute to supplying more than $40 \%$ of the recommended daily fiber intake for children, adults and pregnant women, and thus can be considered an excellent source of this nutrient for the three groups (table $V$ ).

The murici fruit is also highlighted due to its potential for daily supply of vitamin C. Consuming only one portion of the fruit is sufficient to supply $93.7 \%$ of the daily vitamin $\mathrm{C}$ requirement for children, $26.0 \%$ for adults and $29.3 \%$ for pregnant women; it is therefore considered an excellent source of this vitamin [18].

Murici may also be considered a source of vitamin $\mathrm{E}$ for the three groups studied. The potential contribution of vitamin $\mathrm{E}$ was calculated based on the concentration of $\alpha$-tocopherol, as recommended by the Institute of Medicine [37]. It is noteworthy, however, that the presence of $\beta$-tocotrienol found in murici is also very important because of its potent antioxidant action and positive effect on the prevention of chronic diseases such as diabetes mellitus type 2 [38].

\section{Conclusion}

Murici stands out with regard to its nutritional value, and may contribute to supplying daily nutritional requirements,

\section{Table V.}

Potential contribution of the pulp of murici (Byrsonima verbascifolia) from the Cerrado of Minas Gerais to the supply of the daily recommendation of vitamins according to the recommended portion $(86 \mathrm{~g}$ the pulp = 30 units the fruit $=70 \mathrm{kcal})$.

Concentration per serving (calculation based on Resolution no. 39) [35].

\begin{tabular}{cccc}
$\begin{array}{c}\text { Dietary fiber } \\
(\mathrm{g})\end{array}$ & $\begin{array}{c}\text { Vitamin } \mathrm{A} \\
(\mu \mathrm{g})\end{array}$ & $\begin{array}{c}\text { Vitamin } \mathrm{C} \\
(\mathrm{mg})\end{array}$ & $\begin{array}{c}\text { Vitamin } \mathrm{E} \\
(\mu \mathrm{g})\end{array}$ \\
11.67 & 11.49 & 23.43 & 1562.38 \\
\hline
\end{tabular}

Calculation based on the RDA (Recommended Dietary Allowance) [36, 37, 39].

\begin{tabular}{|c|c|c|c|c|c|c|c|c|}
\hline \multirow[t]{2}{*}{ People } & \multicolumn{2}{|c|}{ Dietary fiber } & \multicolumn{2}{|c|}{ Vitamin A } & \multicolumn{2}{|c|}{ Vitamin C } & \multicolumn{2}{|c|}{ Vitamin E } \\
\hline & $\begin{array}{l}\text { RDA } \\
(\mathrm{g})\end{array}$ & $\begin{array}{c}\% \text { of } \\
\text { contribution }\end{array}$ & $\begin{array}{l}\text { RDA } \\
(\mu g)\end{array}$ & $\begin{array}{c}\% \text { of } \\
\text { contribution }\end{array}$ & $\begin{array}{l}\text { RDA } \\
(\mathrm{mg})\end{array}$ & $\begin{array}{c}\% \text { of } \\
\text { contribution }\end{array}$ & $\begin{array}{l}\text { RDA } \\
(\mu g)\end{array}$ & $\begin{array}{c}\% \text { of } \\
\text { contribution }\end{array}$ \\
\hline Children & 25 & 46.68 & 400 & 2.87 & 25 & 93.70 & 7000 & 11.40 \\
\hline Adults & 25 & 46.68 & 800 & 1.43 & 90 & 26.02 & 15000 & 5.44 \\
\hline Pregnant & 28 & 41.67 & 770 & 1.48 & 85 & 29.27 & 15000 & 5.44 \\
\hline
\end{tabular}


particularly dietary fiber and vitamin $\mathrm{C}$, but this fruit is also a source of vitamin $\mathrm{E}$ and contains provitamin A. This fact justifies encouraging its consumption by families living in the Cerrado and also in other regions of Brazil.

\section{Acknowledgments}

The authors thank the CNPq and FAPEMIG, Brazil, for granting scientific initiation and Master's program scholarships, as well as for financial support of this research.

\section{References}

[1] Proença C., Oliveira R.S., Silva A.P., Flores e frutos do Cerrado, UnB, Brasília, Brazil, 2000, 36 p.

[2] Melchior S.J., Custódio C.C., Marques T.A., Neto N.B.M., Colheita e armazenamento de sementes de gabiroba (Campomanesia adamantium Camb. - Myrtaceae) e implicações na germinação, Rev. Bras. Sementes (28) (2006) 141-150.

[3] Anon., Programa Nacional de Conservação e Uso Sustentável do Bioma Cerrado, Brasília, Ministério de meio Ambiente/Secretaria de Biodiversidade e Florestas-Núcleo dos Biomas Cerrado e Pantanal, MMA, 2004.

[4] Mittermeier R.A., Gil P.R., Hoffman M., Pilgrim J., Brooks T., Mittermeier C.G., Lamoureux J., Fonseca G.A.B., Seligmann P.A., Ford H., Hotspots revisited: Earth's biologically richest and most endangered terrestrial ecoregions, CEMEX, Mexico City, Mexico, 2004, 392 p.

[5] Rezende C.M., Fraga S.R., Chemical and aroma determination of the pulp and seeds of murici (Byrsonima crassifolia L.), J. Braz. Chem. Soc. (14) (2003) 425-428.

[6] Alves G.L., Franco M.R.B., Headspace gas chromatography-mass spectrometry of volatile compounds in murici (Byrsonima crassifolia L. Rich), J. Chromatogr. A (985) (2003) 297-301.

[7] Rodriguez-Amaya D.B., Critical review of provitamin A determination in plant foods, $\mathrm{J}$. Micronutr. Anal. (5) (1989) 191-225.
[8] Anon., Normas analíticas do Instituto Adolfo Lutz, IAL, Inst. Adolfo Lutz, São Paulo, Brazil, 2005.

[9] Anon., Official methods of analysis of the Association of Official Analytical Chemists, 16th ed., Assoc. Off. Anal. Chem. (AOAC), Wash., D.C., U.S.A., 1998.

[10] Rodriguez-Amaya D.B., Latin American food sources of carotenoids, Arch. Latinoam. Nutr. 49 (1999) 74-84.

[11] Pinheiro-Sant'Ana H.M., Stringheta P.C., Brandão S.C.C., Azeredo R.M.C., Carotenoid retention and vitamin $A$ value in carrot (Daucus carota L.) prepared by food service, Food Chem. 61 (1998) 145-151.

[12] Anon., Recommended dietary allowances, Natl. Acad. Sci. / Natl. Counc. Res. (NAS/ NCR), Natl. Acad. Press, Wash., D.C., U.S.A., 1989.

[13] Campos F.M., Ribeiro S.M.R., Della Lucia C.M., Pinheiro-Sant'Ana H.M., Stringheta P.C., Optimization of methodology to analyze ascorbic and dehydroascorbic acid in vegetables, Quím. Nova 32 (2009) 87-91.

[14] Pinheiro-Sant'Ana H.M., Guinazi M., Oliveira D.S., Della Lucia C.M., Reis B.L., Brandão S.C.C., Method for simultaneous analysis of eight vitamin $\mathrm{E}$ isomers in various foods by high performance liquid chromatography and fluorescence detection, J. Chromatogr. A 1218 (2011) 8496-8502.

[15] Della Lucia C.M., Silva E.R., Brandão S.C.C., Ribeiro S.M.R., Pinheiro-Sant'Ana H.M., Otimização de método para análise de folatos em hortaliças folhosas por cromatografia líquida de alta eficiência com detecção por fluorescência, Quím. Nova 34 (2010) 335-340

[16] Lanças F.M., Validação de métodos cromatográficos de análise, 6 ed., Rima, São Carlos, Brazil, 2004.

[17] Catharino R.R., Godoy H.T., Lima-Pallone J.A., Metodologia analítica para determinaçãoo de folatos e ácido fólico em alimentos, Quím. Nova 29 (2006) 972-976.

[18] Philippi S.T., Pirâmide dos alimentos: fundamentos básicos da nutrição, Manole, Barueri, Brazil, 2008.

[19] Gusmão E., Vieira F.A., Fonseca E.M., Biometria de frutos e endocarpos de murici (Byrsonima verbascifolia (L.) Rich.), Rev. Cerne (12) (2006) 84-91.

[20] Araújo R.R., Santos E.D., Lemos E.E.P., Alves R.E., Caracterização biométrica de 
frutos e sementes de genótipos de muric (Byrsonima verbascifolia (L.) Rich.) do Tabuleiro costeiro de Alagoas, Rev. Caatinga (22) (2009) 224-228.

[21] Guimarães M.M., Silva M.S., Valor nutricional e características químicas e físicas de frutos de murici-passa (Byrsonima verbascifolia), Ciênc. Tecnol. Aliment. (28) (2008) 817-821.

[22] Salunke D.K., Desai B.B., Postharvest biotechnology of fruits, Flórida 2 (1984) 81-85.

[23] Chitarra M.I.F., Chitarra A.B., Pós-colheita de frutos e hortaliças: Fisiologia da maturação pós-colheita de pêras da cultivar shinsseiki, Pesquisa Agropecuária e Manuseio, ESAL/FAEPE, Lavras, Brazil, 2005.

[24] Canuto G.A.B., Xavier A.A.O., Neves L.C., Benassi M.T., Caracterização físico-química de polpas de frutos da amazônia e sua correlação com a atividade anti-radical livre, Rev. Bras. Frutic. (32) (2010) 1196-1205.

[25] Anon., Dietary Reference Intakes (DRIs): Energy, carbohydrate, fiber, fat, fatty acids, cholesterol, protein, and amino acids, U.S. Inst. Med., Natl. Acad. Press, Wash., D.C., U.S.A., 2005.

[26] Brennan C.S., Dietary fiber, glycemic response, and diabetes, Mol. Nutr. Food Res. 49 (2005) 560-570.

[27] Silva M.R., Lacerda D.B.C.L., Santos G.G. Martins D.M.O., Caracterização química de frutos nativos do Cerrado, Ciênc. Rural (38) (2008) 1790-1793.

[28] Anon., USDA National Nutrient Database for Standard Reference, 24th ed., U.S. Dep. Agric., A.R.S., Wash., D.C., U.S.A., 2013.

[29] Cardoso L.M., Reis B.D.L., Hamacek F.R., Pinheiro-Sant'Ana H.M., Chemical characteristics and bioactive compounds of cooked pequi fruits (Caryocar brasiliense Camb.) from the Brazilian Cerrado, Fruits (68) (2013) 3-14.

[30] Cardoso L.M., Bedetti S.F., Ribeiro S.M.R., Esteves E.A., Pinheiro-Sant'Ana H.M., Jatobá of the Cerrado (Hymenaea stigonocarpa): chemical composition, carotenoids and vitamins in an exotic fruit from the Brazilian Savannah, Fruits (68) (2013) 95-107.

[31] Cardoso L.M., Oliveira D.S., Bedetti S.F., Ribeiro S.M.R., Pinheiro-Sant'Ana H.M., Araticum (Annona crassiflora Mart.) from the Brazilian Cerrado: chemical composition and bioactive compounds, Fruits (68) (2013) 121-134.

[32] Hamacek F.R., Santos P.R.G., Cardoso L.M., Pinheiro-Sant'Ana H.M., Nutritional composition of tamarind (Tamarindus indica L.) from the Cerrado of Minas Gerais, Brazil, Fruits (68) (2013) 381-395.

[33] Souza S.L., Moreira A.P.B., PinheiroSant'Ana H.M., Alencar E.R., Conteúdo de carotenos e provitamina A em frutas comercializadas em Viçosa, Estado de Minas Gerais, Acta Sci. Agron. (26) (2004) 453-459.

[34] Hamacek F.R., Santos P.R.G., Cardoso L.M., Ribeiro S.M.R., Pinheiro-Sant'Ana H.M., Araçá do Cerrado from the Brazilian Savannah: physical characteristics, chemical composition and content of carotenoids and vitamins, Fruits (68) (2013) 467-481.

[35] Anon., Resolução - RDC n ${ }^{\circ} 39$, de 21 de março de 2001, Agência Nacional de Vigilância Sanitária (ANVISA), Brasilia, Brazil.

[36] Anon., Dietary Reference Intakes for thiamin, riboflavin, niacin, vitamin B6, folate, vitamin B12, pantothenic acid, biotin, and choline, U.S. Inst. Med., Natl. Acad. Press, Wash., D.C., U.S.A., 1998.

[37] Anon., Dietary Reference Intakes for vitamin C, vitamin E, selenium, and carotenoids. U.S. Inst. Med., Natl. Acad. Press, Wash., D.C., U.S.A., 2000.

[38] Montonen J., Knekt P., Jãrvinen R., Reunanen A., Dietary antioxidant intake and risk of type 2 diabetes, Diabetes Care (27) (2004) 362-366.

[39] Anon., Dietary Reference Intakes for vita$\min \mathrm{A}$, vitamin $\mathrm{K}$, arsenic, boron, cromium, copper, iodine, iron, manganese, molybdenium, nickel, silicon, vanadium and zinc, U.S. Inst. Med., Natl. Acad. Press, Wash., D.C., U.S.A., 2001. 
El murici, fruto del Cerrado de Minas Gerais en Brasil: características físicas y físico-químicas, casos y concentraciones de los carotenos y de las vitaminas.

Resumen - Introducción. El Cerrado es el bioma más vasto del estado de Minas Gerais en Brasil. Dispone de una importante biodiversidad de especies fruteras, entre las cuales merece distinguirse la presencia del murici (Byrsonima verbascifolia). El objetivo de nuestro trabajo fue el estudio de las características físicas y físico-químicas, los casos y la concentración de los carotenos, de la vitamina $\mathrm{C}$, de la vitamina $\mathrm{E}$ y de los folatos en el fruto de murici, cosechado en el Cerrado de Minas Gerais, en Brasil. Material y métodos. Se determinaron la acidez valorable mediante neutralización volumétrica, el $\mathrm{pH}$ mediante potenciometría, los sólidos solubles mediante refractometría, la humedad con la ayuda de un horno, las cenizas mediante el empleo un horno de mufla, las proteínas mediante el método de micro-Kjeldahl, las fibras alimentarias totales mediante el método gravimétrico no enzimático y los lípidos mediante extracción Soxhlet. Se analizaron los carotenos y la vitamina $C$ mediante HPLC-DAD, y la vitamina $\mathrm{E}$ y los folatos mediante HPLC con detección de fluorescencia. Resultados y discusión. La pulpa de murici contiene $7,47 \mathrm{~g} \cdot 100 \mathrm{~g}^{-1}$ de hidratos de carbono, $5,13 \mathrm{~g} \cdot 100 \mathrm{~g}^{-1}$ de lípidos, $13,58 \mathrm{~g} \cdot 100 \mathrm{~g}^{-1}$ de fibras y $71.58 \mathrm{~g} \cdot 100 \mathrm{~g}^{-1}$ de humedad. El pH, la acidez valorable y los sólidos solubles fueron, respectivamente, de $3,93,0,77 \mathrm{~g} \cdot 100 \mathrm{~g}^{-1}$ de ácido cítrico y de $10,73^{\circ} \mathrm{Brix}$. Los resultados indicaron que el fruto es una fuente excelente de fibras y de vitamina C $(27,24 \mathrm{mg} \cdot 100 \mathrm{~g})^{-1}$, una buena fuente de vitamina $\mathrm{E}\left(1819,72 \mu \mathrm{g} \cdot 100 \mathrm{~g}^{-1}\right)$ para los niños y una fuente para adultos y mujeres embarazadas. No encontramos folatos en el murici. Conclusión. El murici se destaca gracias a su valor nutritivo. Podría contribuir de manera significativa al aporte de elementos nutritivos, sobre todo de fibras y vitamina C. Por lo tanto, el consumo de este fruto debería impulsarse entre las familias residentes en el Cerrado y en otras regiones de Brasil.

Brasil / Byrsonima verbascifolia / frutas / propriedades fisicoquímicas / composición aproxinada / vitamina C / vitamina $\mathrm{E}$ / vitaminas $\mathrm{B}$ 